DAWID ABRAMOWICZ

ORCID 0000-0003-0523-8379

Uniwersytet im. Adama Mickiewicza

$w$ Poznaniu

\title{
ZADANIA DOMOWE W PERSPEKTYWIE UCZNIÓW NA PRZYKŁADZIE PRZEDMIOTU GEOGRAFIA
}

\begin{abstract}
AвSTRACt. Abramowicz Dawid, Zadania domowe w perspektywie uczniów na przyktadzie przedmiotu geografia [Homework in the Students' Perspective - a Case Study of the Subject of Geography]. Studia Edukacyjne nr 55, 2019, Poznań 2019, pp. 245-257. Adam Mickiewicz University Press. ISSN 12336688. DOI: $10.14746 /$ se.2019.55.14

Homework in school education is one of the most important challenges in the educational process. Considerations regarding homework and its efficiency result from various approaches in both academic and school environments. Despite various opinions, discussions and the results of research on education, and at the same time the lack of legal necessity to apply homework, they remain an integral part of the education process in most schools.

The aim of the research was to recognize students' opinions on homework. The study presents the results of research on the use of obligatory and non-obligatory home tasks in geography lessons. According to the students, the use of compulsory homework in a Geography lesson adversely affects their mobilization for learning outside of school. Students pay attention to the problem of a small amount of time that they could devote to the pursuit of their interests. In their opinion, the possibility to decide on the form of homework would significantly increase their motivation to learn.
\end{abstract}

Key words: homework, geographic education, motivation, learning

\section{Wprowadzenie}

Zadania domowe w edukacji szkolnej stanowią jedno z ważniejszych rozważań dotyczących procesu kształcenia. W większości polskich szkół uważane są za element komplementarnie związany z nauką szkolną ${ }^{1}$. Według Wincentego Okonia zadania domowe są

${ }^{1}$ M. Janukowicz, Determinanty efektywności pracy domowej ucznia, Prace Naukowe Akademii im. Jana Długosza w Częstochowie, 2016, 25(2), s. 222. 
formą obowiązkowych, wykonywanych zwykle w domu zajęć szkolnych, których celem jest rozszerzenie, pogłębienie i utrwalenie wiedzy oraz wdrożenie do samodzielności w posługiwaniu się wiedzą, zbieraniu informacji, dokonywaniu obserwacji, rozwiązywaniu zagadnień oraz pisemnym ich opracowaniu².

Uwzględniając sposób przygotowania uczniów do wykonywania pracy domowej, wyróżnia się cztery sposoby różnicowania zadań domowych: a) przydzielenie zadań obowiązkowych, b) wykonywanie zadań dodatkowych przez chętnych uczniów (z własnej inicjatywy), c) przydzielanie zadań dla chętnych uczniów, d) uwzględnianie zadań proponowanych przez uczniów ${ }^{3}$.

Rozważania dotyczące zadań domowych i ich efektywności wynikają z rozmaitych podejść zarówno w środowiskach nauczycieli akademickich, jak szkolnych. W niektórych szkołach obserwuje się odejście od tradycyjnego modelu, w którym akcentuje się uczenie w domu, stymulowane zadaniami dydaktycznymi ${ }^{4}$, na rzecz zwiększania czasu przeznaczonego na wypoczynek uczniów, a także rozwój uzdolnień i zainteresowań ${ }^{5}$. Jak przekonują E. Kralovec i J. Buell ${ }^{6}$, zadania domowe wyraźnie ograniczają czas, który uczniowie powinni poświęcać na budowanie życia rodzinnego i rozwijanie zainteresowań. Do najczęściej wymienianych utrudnień związanych ze stosowaniem zadań domowych zalicza się:

- ograniczone możliwości kontroli, czy zadanie zostało wykonane samodzielnie;

- zagrożenie wykorzystywania gotowych odpowiedzi z innych źródeł, np. Internetu lub zlecenia wykonania zadania osobom trzecim;

- ograniczenie czasu przeznaczonego na wypoczynek, aktywności pozaszkolne, rozwijanie własnych zainteresowań, spotkania z rodziną i przyjaciółmi;

- zagrożenie zjawiskiem tzw. prokrastynacji, czyli odwlekania wykonania zadania oraz problem z utrzymaniem stałej aktywności uczącego się spowodowane tendencją do rozpraszania się w warunkach domowych;

- zagrożenie utraty zainteresowania szkolnym materiałem poprzez poczucie konieczności wykonywania zadań, które mogą być nieatrakcyjne dla ucznia;

\footnotetext{
${ }^{2}$ W. Okoń, Zarys dydaktyki ogólnej, Warszawa 1968, s. 27.

${ }^{3}$ I. Adamek, Podstawy edukacji wczesnoszkolnej, Kraków 2000, s. 96.

${ }^{4}$ A. Łukawska, Nauka domowa uczniów: uwagi kierowane do kandydatów na nauczycieli, Nauczyciel i Szkoła, 2004, 1-2 (22-23), s. 12.

${ }_{5}$ A. Martyka, Czas wolny dzieci we wspótczesnych polskich miastach. Wprowadzenie do poszukiwań optymalnych rozwiazań przestrzennych, Czasopismo techniczne, Architektura, 2012, 29(109), s. 110.

${ }^{6}$ E. Kralovec, J. Buell, End Homework Now, Association for Supervision and Curriculum Development, 2003, s. 39-40.
} 
- możliwość wystąpienia spięć i konfliktów w rodzinie, wpływających na niepowodzenie $\mathrm{w}$ wykonaniu zadania lub wynikających $\mathrm{z}$ udziału domowników w rozwiązywaniu zadań;

- kumulacja zbyt dużej liczby zadań domowych mogąca powodować uczucie przepracowania, spadku motywacji i dobrego samopoczucia.

Przyrost wiedzy szkolnej jest tylko jednym z elementów niezbędnych do prawidłowego rozwoju dziecka ${ }^{7}$.

Jednocześnie, zarówno badacze, jak i nauczyciele przydają nadal wiele zalet zadaniom domowym. Wśród najczęściej wymienianych znajdują się między innymi:

- poprawa osiągnięć szkolnych poprzez utrwalanie w pamięci nabytej wiedzy, a także lepsze jej zrozumienie;

- poprawa samodyscypliny, organizacji pracy i kształtowanie poczucia odpowiedzialności za jej wykonanie';

- kształtowanie nawyku uczenia się, samokształcenia oraz pragnienia sukcesu ${ }^{10}$;

- kształtowanie umiejętności oceny i krytycznego myślenia ${ }^{11}$;

- kształtowanie sprawności potrzebnych do życia w przyszłości ${ }^{12}$.

Pomimo rozmaitych podejść, dyskusji oraz prowadzonych badań, a jednocześnie braku prawnej konieczności ich stosowania, zadania domowe pozostają nieodłączną częścią procesu kształcenia w większości szkół13.

W niniejszym opracowaniu przedstawiono wyniki badań dotyczących stosowania zadań domowych na lekcjach geografii, w podziale na zadania obowiązkowe i nieobowiązkowe. Celem badań było rozpoznanie opinii uczniów na ich temat.

7 I. Adamek, Podstawy edukacji wczesnoszkolnej, s. 96; E. Kralovec, J. Buell, End Homework Now, s. 40; A. Paszkiewicz, Na kim spoczywa odpowiedzialność za prace domowa dziecka, Problemy Opiekuńczo-Wychowawcze, 2014, 1, s. 38; R. Dolata i in., Szkolne pytania. Wyniki badań nad efektywnościa nauczania w klasach IV-VI, Warszawa 2015, s. 96; E. Szkurłat, E-learning w geograficznym ksztatceniu akademickim - szanse, wyzwania, zagrożenia, [w:] Technologie informacyjno-komunikacyjne w geograficznej praktyce edukacyjnej. Prace Komisji Edukacji Geograficznej PTG, red. A. Hibszer, E. Szkurłat, Łódź 2015, s. 64; M. Janukowicz, Determinanty efektywności pracy domowej ucznia, s. 225.

8 W. Okoń, Zarys dydaktyki ogólnej, s. 27.

${ }_{9}$ I. Adamek, Podstawy edukacji wczesnoszkolnej, s. 96.

10 A. Paszkiewicz, Na kim spoczywa odpowiedzialność za pracę domowa dziecka, s. 38.

${ }_{11}$ R. Dolata i in., Szkolne pytania.

${ }_{12}$ M. Janukowicz, Determinanty efektywności pracy domowej ucznia, s. 225.

${ }^{13}$ R. Dolata i in., Szkolne pytania, s. 96; M. Janukowicz, Determinanty efektywności pracy domowej ucznia, s. 225. 


\section{Procedura badawcza}

Badania zostały przeprowadzone $\mathrm{w}$ pierwszym semestrze roku szkolnego 2017/2018 wśród uczniów klasy siódmej szkoły podstawowej oraz klas drugiej i trzeciej gimnazjum (wszystkie klasy o profilu ogólnym), w których nauczyciel stosował nieobowiązkowe i obowiązkowe zadania domowe. W ankiecie wzięło udział 66 uczniów, z czego 35 uczniów stanowiły dziewczęta, a 31 chłopcy. Kwestionariusz ankiety przekazany uczniom składał się z trzech części: 1) dotyczącej zadań nieobowiązkowych, 2) zadań obowiązkowych, 3) refleksji dotyczących form zadań domowych z geografii.

Uczniowie biorący udział $\mathrm{w}$ badaniu mieli doświadczenie związane z otrzymywaniem od nauczyciela nieobowiązkowych i obowiązkowych zadań domowych oraz ich wykonywaniem. W pierwszej części semestru nauczyciel stosował wyłącznie nieobowiązkowe zadania domowe, tłumacząc wcześniej ich ogólną zasadę. Poprawne wykonanie tych zadań wiązało się z otrzymaniem przez ucznia pozytywnej oceny lub tak zwanego plusa. Zadania te dotyczyły między innymi sporządzenia notatki na podany temat, przeczytania i analizy tekstu związanego z tematyką omawianą na lekcji oraz wykonanie do niego poleceń lub odszukiwania i zaprezentowania przed klasą dodatkowych informacji na dany temat. W drugiej części semestru nauczyciel stosował wyłącznie obowiązkowe zadania domowe, które dotyczyły bezpośrednio prezentowanych na lekcji treści, wiązały się z treścią zawartą $\mathrm{w}$ podręczniku lub poruszały zagadnienie problemowe, zawsze związane z podstawą programową nauczania geografii.

\section{Wyniki badań}

\section{Nieobowiązkowe zadania domowe "dla chętnych"}

Ponad 56\% uczniów zadeklarowało, że przynajmniej raz wykonywali zadania nieobowiązkowe z geografii, natomiast $43 \%$ uczniów odpowiedziało, że nigdy nie wykonało zadania nieobowiązkowego (ryc. 1). Ponad 86\% uczniów odpowiedziało, że czynnikiem najbardziej zachęcającym do wykonania nieobowiązkowych zadań domowych jest zdobycie dodatkowej oceny oraz podwyższenie średniej ocen (76\%). Duża część z nich (64\%) deklaruje, że zachętą do wykonywania tych zadań jest możliwość samodzielnego zadecydowania o ich zrobieniu. Interesujące jest, że 44\% uczniów twierdzi, iż ważną zachętą do ich wykonania jest chęć zaimponowania nauczycielowi. Zdecydowanie mniej uczniów deklaruje, że zachętą do wykonywania takich zadań jest dowiedzenie się „czegoś nowego" (24\%) lub zainspirowanie się $(11 \%)$. 


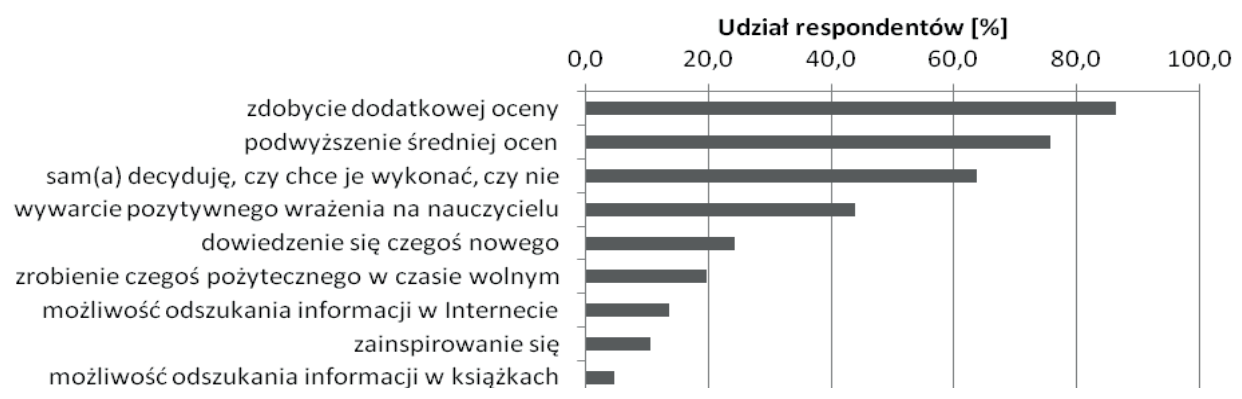

Ryc. 1. Motywy wykonywania zadań nieobowiązkowych przez uczniów

(źródło: opracowanie własne)

Badani uczniowie uznali, że najważniejszymi motywami zachęcającymi ich do wykonywania zadań dodatkowych z geografii są zdobycie dodatkowej oceny $(73 \%)$, podwyższenie średniej ocen (53\%) oraz możliwość samodzielnego zadecydowania o wykonaniu zadania (36\%) - rycina 2.

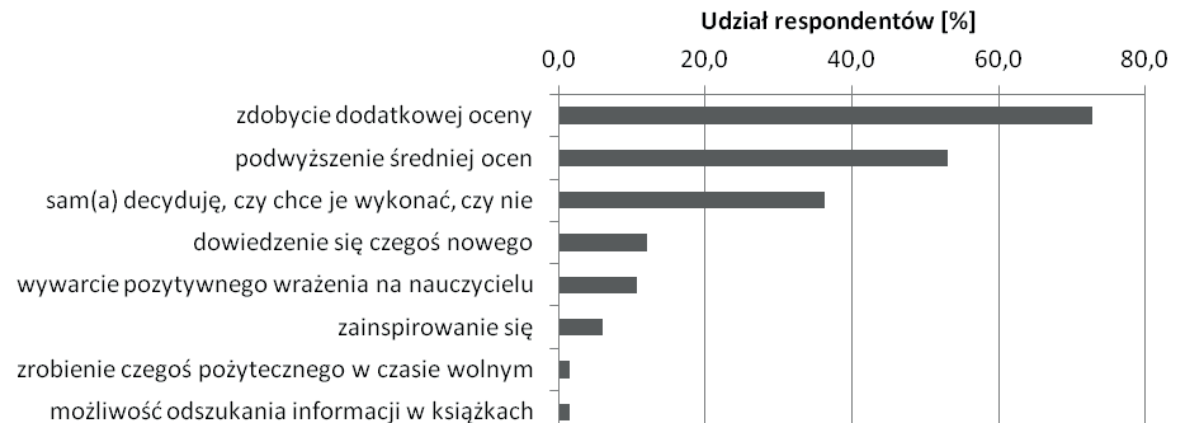

Ryc. 2. Najważniejsze motywy związane z wykonywaniem zadań nieobowiązkowych

(źródło: opracowanie własne)

\section{Obowiązkowe zadania domowe}

Spośród badanych uczniów aż 70\% respondentów przyznało, że zdarzyło się im nie wykonać zadania obowiązkowego z geografii. Jedynie $30 \%$ respondentów zadeklarowało, że zawsze wykonywali obowiązkowe zadania domowe. Z kolei, wśród dostrzeganych motywów wykonywania obowiązkowych zadań domowych z geografii uczniowie najczęściej wymieniają, że jest to sposób na powtórzenie materiału (59\% odpowiedzi). Co trzeci ankietowany odpowiedział, że ważny jest dla niego fakt, iż każdy uczeń musi wykonać to samo zadanie domowe. Co interesujące, 29\% uczniów twierdzi, że korzyst- 
nym aspektem obowiązkowych zadań domowych jest to, że nie podlegają one ocenie (ryc. 3).

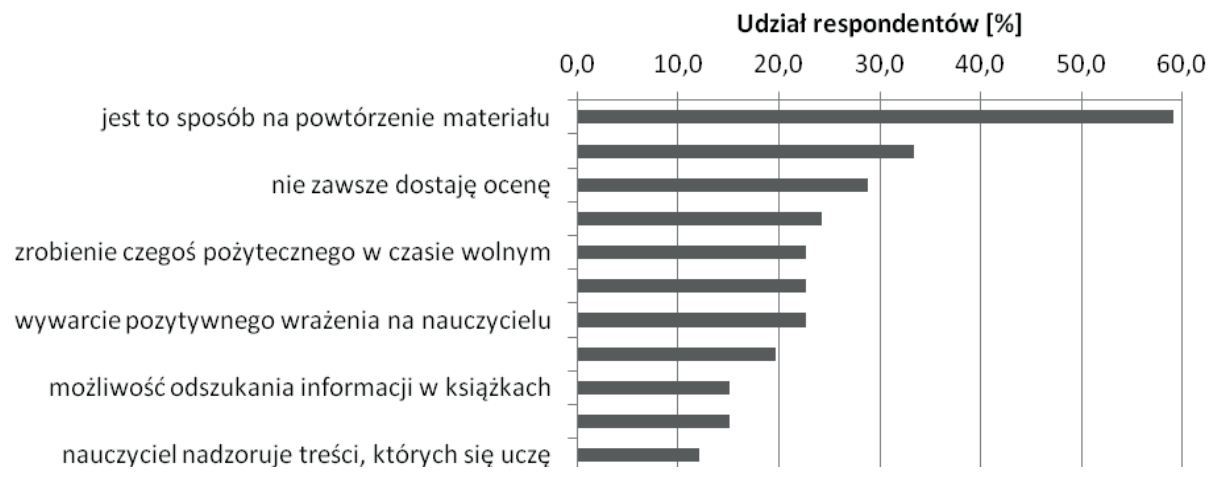

Ryc. 3. Motywy wykonywania zadań obowiązkowych przez uczniów

(źródło: opracowanie własne)

Badani uczniowie potwierdzili, że najważniejszym motywem zachęcającym do wykonania zadania domowego z geografii jest możliwość powtórzenia materiału (58\% odpowiedzi). Ponadto, co czwarty respondent deklaruje, że ważną korzyścią jest to, iż każdy uczeń musi wykonać takie samo zadanie domowe (ryc. 4).

\section{Udział respondentów [\%]}

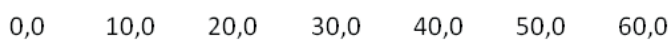

jest to sposób na powtórzenie materiału wszyscy uczniowie muszą zrobić to samo nie zawsze dostaję ocenę wywarcie pozytywnego wrażenia na nauczycielu mogę podrównać odpowiedzi z innymi zrobienie czegoś pożytecznego w czasie wolnym możliwość odszukania informacji w Internecie muszę oddać zadanie w konkretnym czasie możliwość odszukania informacji w książkach inne nauczyciel nadzoruje treści, których się uczę

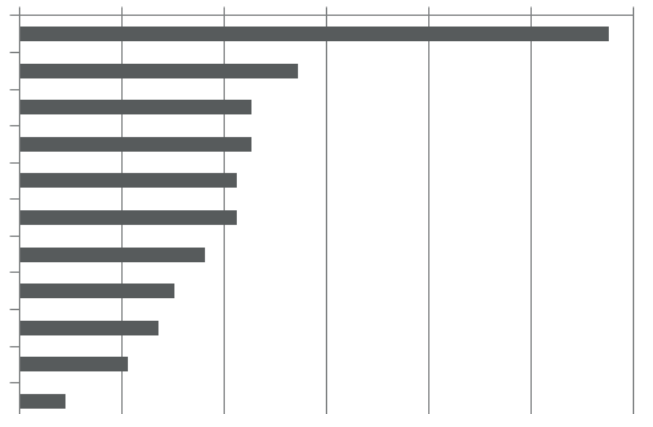

Ryc. 4. Najważniejsze motywy związane z wykonywaniem zadań obowiązkowych (źródło: opracowanie własne) 


\section{Uczenie się w domu}

Zdaniem badanych uczniów, najchętniej wykorzystywanymi metodami utrwalania zdobytej wiedzy podczas lekcji geografii są takie czynności, jak powtarzanie notatek z zeszytu (62\%), a także czytanie tekstu z podręcznika (55\%) - rycina 5. Ponadto, co trzeci uczeń uznał, że wartościowym zajęciem w utrwalaniu wiedzy geograficznej jest oglądanie filmów dokumentalnych o tematyce przyrodniczej (35\%) oraz wykonywanie obowiązkowych zadań domowych $(30 \%)$.

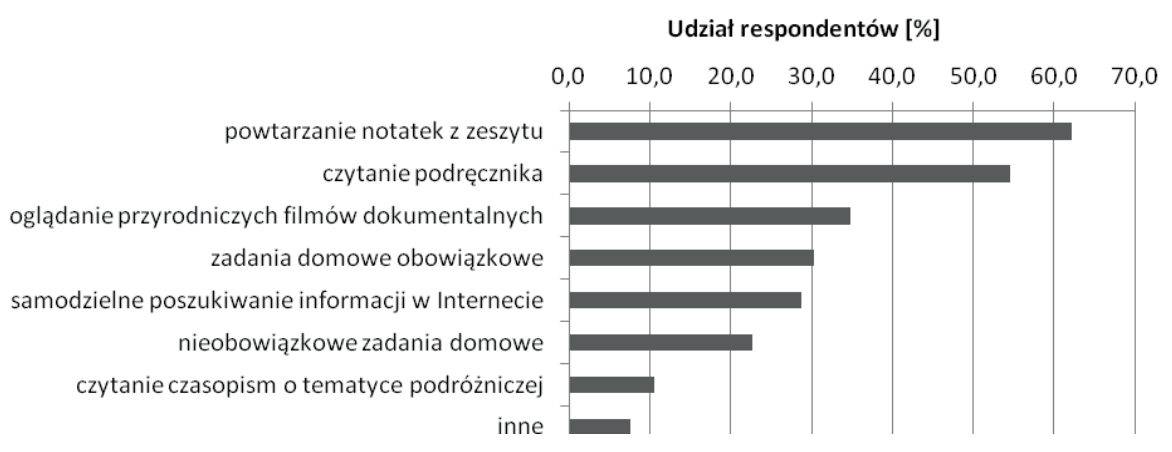

Ryc. 5. Najczęstsze metody utrwalania zdobytej wiedzy w opinii uczniów

(źródło: opracowanie własne)

W odniesieniu do czynności pomagających uczniom w pozyskaniu nowych informacji o tematyce geograficznej (ryc. 6), najczęściej deklarowano, że są to takie czynności, jak samodzielne poszukiwanie informacji w Interne-

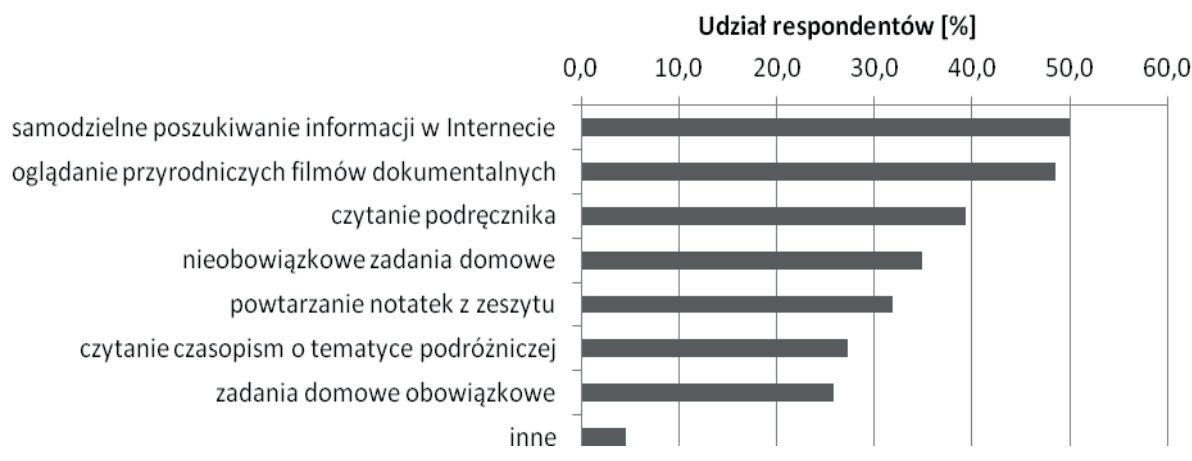

Ryc. 6. Czynności najczęściej podejmowane przez uczniów pozwalające pozyskać nowe informacje o tematyce geograficznej

(źródło: opracowanie własne) 
cie $(50 \%)$ oraz oglądanie filmów dokumentalnych o tematyce przyrodniczej (49\%). Ponadto, duży udział odpowiedzi dotyczy czytania tekstu z podręcznika (39\%) oraz wykonywania nieobowiązkowych zadań domowych (35\%).

Zdecydowana większość badanych uczniów zadeklarowała (74\%), że wolałaby otrzymywać nieobowiązkowe zadania domowe. Obowiązkowe zadania domowe jako chętniej wykonywane zostały wybrane przez 15\% uczniów, a $11 \%$ podało inne odpowiedzi.

Uczniowie argumentujący swoją aprobatę dla nieobowiązkowych zadań domowych najczęściej zwracali uwagę na brak konieczności ich wykonania. Zdaniem tych uczniów, w sytuacji dużej liczby kartkówek i sprawdzianów mogą nie wykonać nieobowiązkowego zadania, nie ponosząc jednocześnie konsekwencji, a zaoszczędzony czas poświęcić na przygotowanie się do form sprawdzenia wiedzy. Uczniowie uznali, że zaoszczędzony czas mogą też wykorzystać dla własnych potrzeb, między innymi na odpoczynek i rekreację.

W wyraźny sposób badani uczniowie zwrócili uwagę na kwestię oceniania. Głównymi argumentami prezentowanymi przez nich jest brak ponoszenia konsekwencji za niewykonanie zadania, a tym samym nieuzyskanie negatywnej oceny. W odpowiedziach uczniowie zwracają uwagę na stresujące sytuacje, powstające $\mathrm{z}$ niewykonania obowiązkowego zadania domowego. Natomiast nieobowiązkowe zadanie domowe nie jest związane z odczuwaniem stresu. Respondenci argumentują, że otrzymanie pozytywnej oceny poprawia średnią ocen, co powoduje zwiększenie mobilizacji do uczenia się. Ważnym aspektem podkreślanym przez uczniów jest fakt, że za wykonanie takiego zadania można otrzymać dobrą ocenę cząstkową.

Ponadto, w odpowiedziach uczniów dotyczących korzyści wynikających z wykonywania nieobowiązkowych zadań domowych stwierdzono, że zadania te są ciekawsze i bardziej skutecznie pozwalają na zainteresowanie się geografią. Ponadto, według uczniów, ich wykonanie powoduje, że można wywrzeć na nauczycielu dobre wrażenie.

W przypadku obowiązkowych zadań domowych uczniowie nielicznie wymieniają ich korzyści. Przede wszystkim podkreślono, że zadania te muszą zostać wykonane konsekwentnie przez wszystkich uczniów, przez co czują się traktowani sprawiedliwie. Zwrócono również uwagę na to, że obowiązkowość wykonania zadania domowego mobilizuje do podejmowania konkretnych działań, co owocuje zdobyciem lub utrwaleniem wiedzy. Jedna osoba odpowiedziała, że zadania obowiązkowe uczą odpowiedzialności. Natomiast inna stwierdziła, że stosowanie obu form zadań domowych daje najlepszy rezultat. Pozostałe odpowiedzi nawiązywały do tego, że w szkole nie powinno stosować się żadnych zadań domowych. 


\section{Dyskusja wyników}

W przeprowadzonych badaniach mających na celu rozpoznanie opinii uczniów na temat zadań domowych stosowanych na lekcjach geografii stwierdzono, że większość uczniów chętnie podejmuje się wykonywania dodatkowych zadań domowych. Jak dowodzą badania przeprowadzone przez R. Dolatę i innych, pomimo że uczniowie poświęcają swój czas na ich wykonywanie, to jednocześnie oceniają, że czas ten jest wykorzystany efektywnie. Uczniowie deklarujący częste i bardzo częste wykonywanie nieobowiązkowych zadań domowych cechują się większym przyrostem wiedzy ${ }^{14}$.

Na podstawie wyników badań należy stwierdzić, że najczęstszą zachętą do wykonywania nieobowiązkowych zadań domowych z geografii jest zdobycie dodatkowej oceny i podwyższenie średniej ocen. Wśród wysoko ocenianych przez uczniów motywacji występuje również fakt samodzielnego zadecydowania o wykonaniu zadania oraz wywarcie pozytywnego wrażenia na nauczycielu. Istotę samodzielnego decydowania o podejmowanej pracy przez uczniów opisuje $\mathrm{w}$ pracy C. Freinet ${ }^{15}$, zwracając uwagę, że swoboda wyboru zadań przez uczniów i brak konieczności podporządkowywania się wyzwalają większe zaangażowanie. Interesujące jest również to, że tylko dla co dziesiątego respondenta ważna jest możliwość zainspirowania się podczas wykonywania dodatkowych zadań domowych. Jak podkreśla A. Hłobii1" znaczący wzrost motywacji wśród uczniów, rozwój zdolności i zainteresowań powoduje indywidualizacja nauczania, w tym przypadku również na etapie planowania dodatkowych zadań domowych z geografii.

Przeprowadzone badania dowodzą, że 70\% respondentów zadeklarowało, że zdarzyło się im nie wykonać obowiązkowego zadania domowego z geografii. Jedną z przyczyn może być stwierdzenie A. Martyki ${ }^{17}$, która przekonuje, że młodzież dysponuje coraz mniejszą ilością czasu wolnego. Jednocześnie uczniowie zwracają uwagę, że główną korzyścią z wykonywania zadań domowych nie jest zdobycie nowej wiedzy, a przeciwnie - powtórzenie materiału. W tym kontekście istotny problem związany z zadaniami obowiązkowymi porusza A. Brzezińska ${ }^{18}$, zwracając uwagę na to, że ich zbyt częsta obecność, a jednocześnie nadmierna kontrola mogą spowodować ubezwła-

${ }^{14}$ R. Dolata i in., Szkolne pytania, s. 107.

15 C. Freinet, Niezawodne prawdy pedagogiczne, Otwock 1993, s. 10-11.

${ }^{16}$ A. Hłobił, Indywidualizacja kształcenia szansą urzeczywistnienia potrzeb i możliwości uczniów, Edukacja Humanistyczna, 2015, 1(32), s. 118.

17 A. Martyka, Czas wolny dzieci we wspótczesnych polskich miastach, s. 116.

18 A. Brzezińska, Nauczyciel jako organizator społecznego środowiska uczenia się, [w:] Rozwijanie zdolności uczenia się. Wybrane konteksty i problemy, red. E. Filipiak, Bydgoszcz 2009, s. 7. 
snowolnienie ucznia, doprowadzając do stłumienia ciekawości poznawczej, a jednocześnie znacznego obniżenia motywacji, aby obowiązkowe zadania domowe wykonać ${ }^{19}$. Co ciekawe, inną ważną korzyścią wykonywania obowiązkowych zadań domowych, która została określona przez uczniów jest to, że są one sprawiedliwie skierowane do wszystkich, a ich wykonanie często nie podlega ocenie.

Należy również zwrócić uwagę, że w pytaniu o najlepszą metodę utrwalenia wiedzy zdobytej podczas lekcji uczniowie ocenili znacznie wyżej możliwość powtórzenia z notatek z zeszytu lub pracę z podręcznikiem, aniżeli wykonywanie obowiązkowych prac domowych. Podobnego zdania jest A. Głowacz ${ }^{20}$, który argumentuje, że podstawą samokształcenia uczniów przy powtórkach jest praca z podręcznikiem, a zwłaszcza jego lektura.

Interesujące informacje uzyskano $\mathrm{w}$ pytaniu dotyczącym pozyskiwania nowych informacji w dziedzinie geografii, gdzie tylko co czwarty respondent zadeklarował, że obowiązkowe zadania domowe stanowią źródło nowej wiedzy. W celu pozyskania nowych informacji w zakresie geografii poza lekcją, uczniowie najczęściej deklarują poszukiwanie informacji w Internecie $(50 \%)$ oraz oglądanie filmów dokumentalnych (48\%), a w dalszej kolejności lekturę podręcznika (39\%) i wykonywanie nieobowiązkowych zadań domowych $(35 \%)$. Podobne wyniki badań uzyskała N. Tomczewska-Popowycz ${ }^{21}$, która stwierdza, że uczniowie najczęściej pozyskują nowe informacje z zasobów internetowych oraz filmów wideo. Jak przekonuje M. Groenwald ${ }^{22}$, nauczyciele powinni wykazywać postawę otwartości wobec wykorzystywania nowych mediów, zachęcając epizodycznie do poszukiwania w ten sposób nowych informacji. Źródła internetowe mogą też służyć jako rozwijanie nowych umiejętności, zwłaszcza kiedy związane są z wykorzystywaniem oprogramowania opartego na GIS $^{23}$ lub aplikacji udostępnianych w formie QR-kodów ${ }^{24}$. Nale-

${ }^{19}$ K. Dacy-Ignatiuk, Platforma edukacyjna EDMODO w praktyce szkolnej, [w:] Technologie w informacyjno-komunikacyjne w geograficznej praktyce edukacyjnej, s. 180.

20 A. Głowacz, Umiejętności ksztatcone za pomoca podręczników do geografii w Polsce, Anglii, Francji i Niemczech (Saksonii), [w:] Edukacja geograficzna na świecie i w Polsce - wybrane problemy, Prace Komisji Edukacji Geograficznej PTG, red. E. Szkurłat, A. Głowacz, Łódź 2014, s. 133.

${ }^{21} \mathrm{~N}$. Tomczewska-Popowycz, Technologie informacyjno-komunikacyjne na lekcjach geografii w opinii uczniów szkół ponadgimnazjalnych, [w:] Technologie informacyjno-komunikacyjne w kształceniu geograficznym. Założenia teoretyczne. Diagnoza wykorzystania, Prace Komisji Edukacji Geograficznej PTG, red. A. Hibszer, E. Szkurłat, Łódź 2015, s. 143.

${ }^{22}$ M. Groenwald, Nauczyciel geografii w świecie nowych mediów, [w:] Tamże, s. 16.

${ }_{23}$ A. Głowacz, Teoretyczne i praktyczne aspekty wykorzystania GIS w szkolnej edukacji geograficznej, [w:] Technologie w informacyjno-komunikacyjne w geograficznej praktyce edukacyjnej, s. 75-76; M. Groenwald, Nauczyciel geografii w świecie nowych mediów, s. 16; M. Adamczewska, I. Pawelczyk, Multimedia w kształceniu geograficznym - przykład gimnazjów w Łodzi, [w:] Technologie informacyjno-komunikacyjne w ksztatceniu geograficznym, s. 163.

${ }^{24}$ I. Piotrowska, M. Cichoń, Multimedia i e-podręczniki w ksztatceniu młodzieży pokolenia cyfrowego, [w:] Technologie informacyjno-komunikacyjne w kształceniu geograficznym, s. 71; P. Pytka, 
ży jednak zwracać uwagę na zachowanie umiaru w korzystaniu ze źródeł internetowych tak, aby nie dopuścić do nadmiernego ich wykorzystywania $\mathrm{w}$ trakcie nauki ${ }^{25}$.

Wyniki przeprowadzonych badań informują, że zdecydowana większość uczniów preferuje stosowanie na lekcjach geografii zadań domowych, które skierowane są tylko dla chętnych. Według uczniów, brak konieczności ich wykonania pozwala im wykorzystać czas wolny zgodnie z własnym przekonaniem lub przeznaczyć go na naukę do kartkówek lub sprawdzianów. Podobnego zdania jest A. Martyka ${ }^{26}$, twierdząc, że rezygnowanie z prac domowych na rzecz czasu wolnego umożliwia stymulowanie wszechstronnego rozwoju młodzieży. Ponadto, wykonywanie zadań dodatkowych przez uczniów jest umotywowane podwyższeniem średniej ocen. Przedstawiane powody wykonywania przez uczniów zadań dodatkowych są niepokojące, ponieważ nie wynikają głównie z chęci zwiększenia swojej wiedzy, a kalkulacji związanych z ocenami szkolnymi. Jak przekonuje A. Brzezińskaa ${ }^{27}$, ważną rolę $\mathrm{w}$ tym zakresie powinni odgrywać nauczyciele, umiejętnie formułując zadania domowe, co może mieć pozytywny wpływ na efektywność uczenia się $\mathrm{w}$ domu. Uczniowie nie mają obaw co do tego, że za niewykonanie zadania nieobowiązkowego mogliby otrzymać negatywną ocenę. Korzyścią wykonywania zadań dodatkowych jest też możliwość zaimponowania nauczycielowi, jak również odnalezienie ciekawej informacji, natomiast wykonywania zadań obowiązkowych - możliwość powtórzenia materiału oraz fakt sprawiedliwego traktowania uczniów.

\section{Podsumowanie}

Przeprowadzone badania informują, że uczniowie preferują otrzymywanie na lekcjach geografii nieobowiązkowych zadań domowych niż tych, które zobligowani są wykonać. Oznacza to, że uczniowie dużo chętniej wykonują zadania, jeśli mają możliwość ich wyboru. Jednocześnie deklarują, że głównym motywem wyboru nieobowiązkowych zadań domowych jest zdobycie lepszej oceny i poprawienie średniej ocen, co powinno skłonić nauczycieli do refleksji nad obowiązującym w wielu szkołach systemem oceniania. Od kreatywności i umiejętności nauczycieli zależy jednak, jaką formę mają zadania, a tym samym, jak bardzo uczniowie będą zmobilizowani do ich wykonania.

P. Wojtanowicz, Fotokod QR nowym sposobem przekazu informacji w edukacji, [w:] Edukacja geograficzna wobec problemów wspótczesnego świata, s. 129-130

${ }_{25}$ A. Hibszer, E. Szkurłat, Wstęp, [w:] Technologie w informacyjno-komunikacyjne w geograficznej praktyce edukacyjnej, s. 7-8.

26 A. Martyka, Czas wolny dzieci we wspótczesnych polskich miastach, s. 109.

27 A. Brzezińska, Nauczyciel jako organizator społecznego środowiska uczenia się, s. 11. 
Na szczególną uwagę zasługuje to, że uczniowie często podkreślają fakt dysponowania niewielką ilością wolnego czasu poza szkołą. Jak podkreślają, głównym powodem tego problemu jest kumulacja obowiązkowych zadań domowych, które uniemożliwiają im realizowanie własnych zainteresowań. Warto jednak pamiętać, że efektywne wykorzystanie czasu poza szkołą, szczególnie na aktywności związane z zainteresowaniami, są istotnym elementem rozwoju młodych ludzi. Problem ilości czasu wolnego uczniów jest ważnym zagadnieniem, które powinno skłaniać środowiska nauczycieli do rozważań nad formami stosowanych zadań domowych.

W świetle wymienianych przez uczniów i nauczycieli zalet oraz wad przypisywanych obecności zadań domowych wydaje się, że dotychczasowe założenia tak zwanej szkoły tradycyjnej we współczesnych realiach edukacyjnych nie sprawdzają się. Wyniki badań dotyczących zadań domowych przeprowadzonych wśród uczniów na lekcjach geografii dowodzą, że uczniowie chcieliby mieć większy wpływ na decyzje o formach uczenia się poza szkołą, co niewątpliwie korzystnie wpłynęłoby na ich motywacje do samodzielnej nauki.

\section{BIBLIOGRAFIA}

Adamczewska M., Pawelczyk I., Multimedia w ksztatceniu geograficznym - przykład gimnazjów w Łodzi, [w:] Technologie informacyjno-komunikacyjne w ksztatceniu geograficznym. Założenia teoretyczne. Diagnoza wykorzystania, Prace Komisji Edukacji Geograficznej PTG, red. A. Hibszer, E. Szkurłat, Wydawnictwo CUK, Łódź 2015.

Adamek I., Podstawy edukacji wczesnoszkolnej, Oficyna Wydawnicza Impuls, Kraków 2000.

Brzezińska A.I., Nauczyciel jako organizator społecznego środowiska uczenia się, [w:] Rozwijanie zdolności uczenia się. Wybrane konteksty i problemy, red. E. Filipiak, Wydawnictwo UKW, Bydgoszcz 2009.

Dacy-Ignatiuk K., Platforma edukacyjna EDMODO w praktyce szkolnej, [w:] Technologie informacyjno-komunikacyjne w geograficznej praktyce edukacyjnej. Prace Komisji Edukacji Geograficznej Polskiego Towarzystwa Geograficznego PTG, red. A. Hibszer, E. Szkurłat, Wydawnictwo CUK, Łódź 2015.

Dolata R., Grygiel P., Jankowska D., Jarnutowska E., Jasińska-Maciążek A., Karwowski M., Modzelewski M., Pisarek J., Szkolne pytania. Wyniki badań nad efektywnościa nauczania w klasach IV-VI, Instytut Badań Edukacyjnych, Warszawa 2015.

Freinet C., Niezawodne prawdy pedagogiczne, PSAPF, Otwock 1993.

Głowacz A., Umiejętności kształcone za pomoca podręczników do geografii w Polsce, Anglii, Francji i Niemczech (Saksonii), [w:] Edukacja geograficzna na świecie i w Polsce - wybrane problemy, Prace Komisji Edukacji Geograficznej PTG, red. E. Szkurłat, A. Głowacz, Wydawnictwo Uniwersytetu Łódzkiego, Łódź 2014.

Głowacz A., Teoretyczne i praktyczne aspekty wykorzystania GIS w szkolnej edukacji geograficznej, [w:] Technologie informacyjno-komunikacyjne w geograficznej praktyce edukacyjnej, Prace Komisji Edukacji Geograficznej PTG, red. A. Hibszer, E. Szkurłat, Wydawnictwo CUK, Łódź 2015. 
Groenwald M., Nauczyciel geografii w świecie nowych mediów, [w:] Technologie informacyjno-komunikacyjne w kształceniu geograficznym. Założenia teoretyczne. Diagnoza wykorzystania, Prace Komisji Edukacji Geograficznej PTG, red. A. Hibszer, E, Szkurłat, Wydawnictwo CUK, Łódź 2015.

Hibszer A., Szkurłat E., Wstęp, [w:] Technologie informacyjno-komunikacyjne w geograficznej praktyce edukacyjnej, Prace Komisji Edukacji Geograficznej PTG, red. A. Hibszer, E. Szkurłat, Wydawnictwo CUK, Łódź 2015.

Hłobił A., Indywidualizacja kształcenia szansa urzeczywistnienia potrzeb i możliwości uczniów, Edukacja Humanistyczna, 2015, 1(32).

Janukowicz M., Determinanty efektywności pracy domowej ucznia, Prace Naukowe Akademii im. Jana Długosza w Częstochowie, 2016, 25(2).

Kralovec E., Buell J., End Homework Now, Association for Supervision and Curriculum Development, ECSCO Publishing, 2003.

Łukawska A., Nauka domowa uczniów: uwagi kierowane do kandydatów na nauczycieli, Nauczyciel i Szkoła, 2004, 1-2 (22-23).

Martyka A., Czas wolny dzieci we wspótczesnych polskich miastach. Wprowadzenie do poszukiwań optymalnych rozwiąań przestrzennych, Czasopismo techniczne, Architektura, 2012, 29(109).

Okoń W., Zarys dydaktyki ogólnej, Państwowe Zakłady Wydawnictw Szkolnych, Warszawa 1968.

Paszkiewicz A., Na kim spoczywa odpowiedzialność za pracę domowa dziecka, Problemy Opiekuńczo-Wychowawcze, 2014, t. 1.

Piotrowska I., Cichoń M., Multimedia i e-podręczniki w kształceniu młodzieży pokolenia cyfrowego, [w:] Technologie informacyjno-komunikacyjne w ksztatceniu geograficznym. Założenia teoretyczne. Diagnoza wykorzystania, Prace Komisji Edukacji Geograficznej PTG, red. A. Hibszer, E. Szkurłat, Wydawnictwo CUK, Łódź 2015.

Pytka P., Wojtanowicz P., Fotokod QR nowym sposobem przekazu informacji w edukacji, [w:] Edukacja geograficzna wobec problemów wspótczesnego świata, Prace Komisji Edukacji Geograficznej PTG, red. J. Rodzoś, E. Szkurłat, Bugucki Wydawnictwo Naukowe, Poznań 2017.

Szkurłat E., E-learning w geograficznym kształceniu akademickim - szanse, wyzwania, zagrożenia, [w:] Technologie informacyjno-komunikacyjne w geograficznej praktyce edukacyjnej, Prace Komisji Edukacji Geograficznej PTG, red. A. Hibszer, E. Szkurłat, Wydawnicwo CUK, Łódź 2015.

Tomczewska-Popowycz N., Technologie informacyjno-komunikacyjne na lekcjach geografii w opinii uczniów szkot ponadgimnazjalnych, [w:] Technologie informacyjno-komunikacyjne w kształceniu geograficznym. Założenia teoretyczne. Diagnoza wykorzystania, Prace Komisji Edukacji Geograficznej PTG, red. A. Hibszer, E. Szkurłat, Wydawnictwo CUK, Łódź 2015. 